\title{
TEOLOGIA KSZTAŁTUJE OBLICZE SEMINARIUM DUCHOWNEGO (2017)
}

Seminarium Duchowne, jako szkoła wyższa, zachowując uniwersytecką tożsamość, ma świadomość powagi kształcenia teologicznego we współczesnym świecie akademickim. Teologia już przed wiekami, współtworzyła wielkie uniwersytety średniowieczne, zwłaszcza w Paryżu, Oksfordzie i Cambridge. Dlatego wytrwale podtrzymujemy ówczesne przekonanie - wbrew lekceważeniu, a niekiedy tendencjom do redukcji, a nawet eliminacji teologii ze świata akademii - że theologia to domina. Inne nauki, a zwłaszcza filozofia pozostają w jej służbie jako ancillae. Albowiem z trzech tzw. dyscyplin wyższych na uniwersytecie - teologia, prawo i medycyna - to teologia była przez wieki uznawana za najważniejszą, a zarazem najtrudniejszą, dzięki czemu znana była jako domina theologia.

Teologia $\mathrm{w}$ relacjach $\mathrm{z}$ innymi dziedzinami i dyscyplinami nauki to uprzywilejowana dziedzina, punkt spotkania, namysłu, nierzadko także sporu. I to w wymiarze tak przedmiotowym - gdy Bóg jako osoba jest przedmiotem namysłu, jak i podmiotowym - współmyśląc $\mathrm{z}$ drugim, współmyślę z osobą sam będąc osobą. Może właśnie tutaj ujawnia się dalsza implikacja tego, o czym pisał św. Jan Paweł II w fundamentalnej dla świata uniwersytetów katolickich konstytucji Ex corde Ecclesiae, gdy wskazywał na nieodzowność teologii nie tylko na uniwersytetach katolickich, ale w świecie nauki w ogóle - bo to teologia ukazuje innym naukom „perspektywę i nadaje kierunek, o których nie mówią ich własne metodologie”, a jednocześnie to teologia „odgrywa szczególnie ważna rolę $\mathrm{w}$ poszukiwaniu syntezy wiedzy, a także $\mathrm{w}$ dialogu między wiarą i rozumem"1. Dzięki bowiem teologii, lepiej poznajemy współczesny, zmieniający się świat, jego problemy i niepokoje, ale i drogi rozwoju czy badań.

Jeśli to osoba jest w centrum refleksji, to teologowie wiedzą dobrze, że idzie o coś więcej niż o zdefiniowanie człowieka jako podmiotu; w pojęciu osoby ujawnia się sam Bóg, bo to z Niego i na Jego obraz człowiek jest osobą. W tym sensie nie chodzi więc o jakiś antropocentryzm, ale raczej o teo-, a bardziej jeszcze chrystocentryzm, gdyż „tajemnica człowieka wyjaśnia się naprawę dopiero w tajemnicy Słowa Wcielonego"?

To pokorne, ale i wytrwałe poszukiwanie prawdy o człowieku jako osobie, a bardziej jeszcze najpierw o samym Bogu i dopiero w Jego świetle

Jan Paweł II, Konstytucja apostolska Ex corde Ecclesiae, Watykan: LEV 1990, nr 19.

2 Sobór Watykański II, Konstytucja duszpasterska o Kościele w świecie współczesnym Gaudium et spes (1965), $\mathrm{nr} 22$. 
o człowieku, to krok na drodze do poznania całej prawdy. Wiemy zarazem, jak to podkreślał Benedykt XVI w planowanym do wygłoszenia na Uniwersytecie Sapienza w Rzymie, choć nie wygłoszonym wykładzie, którego tekst został jednak udostępniony publicznie, że „prawda nie jest nigdy wyłącznie teoretyczna", bo

prawda oznacza coś więcej niż wiedza - celem poznania prawdy jest poznanie dobra [...]. Prawda sprawia, że stajemy się dobrzy, a dobro jest prawdziwe: tym optymizmem żyje wiara chrześcijańska, gdyż jej zostało dane zobaczyć Logos, stwórczy Rozum, który we wcieleniu Boga objawił się zarazem jako Dobro, jako sama Dobroć3.

Seminaria Duchowne w świecie 8 grudnia 2016 roku otrzymały nowe $R a$ tio fundamentalis, czyli tzw. podstawy programowe instytucjonalnego kształcenia przyszłych kapłanów, które podpisał papież Franciszek. Na jego bazie prowadzone są prace przy Konferencji Episkopatu Polski służące wypracowaniu dokumentu wytyczającego nowe perspektywy do pracy Seminariów w Polsce.

Świat uniwersytecki w Polsce kolejny raz staje wobec reformy nauki i szkolnictwa wyższego. Chcemy, czy nie chcemy, zmiany te w jakiś sposób dotkną i nas, i to nie tylko w sferze samej dydaktyki. Coraz bardziej ujawniają się bowiem w zarządzaniu nauką i w samej nauce tendencje do rezygnacji z veritas na rzecz usus. Myślenie pragmatyczne coraz powszechniej dominuje, a kryterium użyteczności dla wielu stoi na pierwszym miejscu. Czy więc jest tu jeszcze miejsce na Augustynową gaudium de veritate, czyli radość $\mathrm{z}$ prawdy?

Mam nadzieję, że nasze Seminarium będzie dla przyszłych kapłanów ciągle miejscem przyjaznego spotkania i owocnego poszukiwania prawdy o Bogu osobowym, o osobie ludzkiej, a sami klerycy staną się w taki sposób źródłem zawsze potrzebnej inspiracji dla Kościoła. Jako uczelnia chcemy pozostać w dialogu i solidarności z innymi naukami i środowiskami naukowymi, ale także uważnego namysłu, a nawet rachunku sumienia, co zawsze nam jest potrzebne, by jak najlepiej służyć tak Bogu, jak i sprawie człowieka.

Oby kolejny rok pracy w najstarszej uczelni miasta przynosił nie tylko osiągnięcia sportowe, czy intelektualne, ale przede wszystkim przyczyniał się do zbliżania się w stronę pełnej prawdy o świecie, człowieku i jego przeznaczeniu, jakim jest prawda wpisana w Boga.

Rok akademicki 2017/2018 uważam za otwarty!

Quod felix, faustum fortunatumque sit!

\section{ks. dr hab. Andrzej Proniewski, prof. UwB}

Benedykt XVI, O poszukiwaniu prawdy [niewygłoszony wykład przygotowany na inaugurację roku akademickiego na Uniwersytecie Rzymskim, 17.01.2008], w: Benedykt XVI, Poznanie prawdy. Wykłady papieskie, Kraków, s. 67. 